\title{
The Effect of Mindfulness-Based Stress Reduction Therapy on Psychological Well-Being in Moms of Mental Retarded Children at SLB C Dharma Wanita Pare Kediri
}

\author{
Reni Nurhidayah ${ }^{1}$, Nurafia \\ Zuhara $^{2}$ \\ ${ }^{1}$ Lecturer of Strada Indonesia Health \\ Sciences Institute \\ ${ }^{2}$ Student in Bhakti Mulia Health \\ Sciences Institute \\ Email: \\ reni.rere.nurhidayah@gmail.com
}

Received : May $9^{\text {th }} 2021$

Accepted : May 10 2021

Published : May 20 2021

\begin{abstract}
Mothers of mentally retarded children have excessive burdens in caring for their children. This is often stressful. Therefore, various therapies are needed and one of them is mindfulnessbased stress reduction therapy. The purpose of this study was to determine the effect of mindfulness-based stress reduction therapy on the psychological well-being of mothers of children with mental retardation.

The research design was quasi-experimental with one group pretest posttest approach. The population was all mothers of children with mental retardation in SLB-C Dharma Wanita PareKediri with a sample of 15 respondents taken by purposive sampling technique and using T-test data analysis.

From the results of the study, it is known that the average psychological well-being score of mothers in caring for mentally retarded children before the mindfulness-based stress reduction therapy is 80.6 with the lowest score is 78 and the highest is 83 , while after that the average score is 117.07 with the lowest score 114 the highest is 123. T-test analysis show of p-value $=0.000$ ( $\mathrm{p}$ value $<0.05$, so $\mathrm{H} 0$ is rejected). This is due to the provision of mindfulness therapy (full awareness), the mother begins to realize that caring for a child who is experiencing mental retardation is an experience here at this time that must be faced. It was concluded that mindfulness-based stress reduction therapy was effective in improving psychological well-being for mothers of mentally retarded children. It is recommended that the nursing profession adopt mindfulness-based stress reduction therapy to increase psychological well-being for mothers of mentally retarded children.
\end{abstract}

Keywords: Mindfulness-based stress reduction therapy, psychological well-being, mothers, mentally retarded children

International License.

\section{INTRODUCTION}

Mental retardation is a worldwide problem, with profound implications, especially for developing countries. Mental retardation is also a dilemma and a source of anxiety for families and communities. Providing a diagnosis of mental retardation in children is not easy. The diagnosis of 
mental retardation should be made at school or the age of 6 years and over. The diagnosis of mental retardation in children can respond emotionally to parents and their families. This event will require a considerable psychological adjustment to the parents which will cause the danger of loss and psychological weakness (Mubashir, 2015).

The results of the report from the World Health Organization (WHO), 2006, based on the standard score of the intelligence category of the American Association of Mental Retardation (AAMR) mental disorders is a disease in Indonesia that ranks tenth in the world, while data from the Central Bureau of Statistics (BPS) in 2006, Out of 222 million Indonesians, 0.7\% or 2.8 million people are disabled, while the population of mentally retarded children is the largest compared to the number of children with other disabilities. The prevalence of mental retardation in Indonesia is estimated to be $1-3 \%$ of the population of around 6.6 million people (Fitriya, 2014).

In 2011, there were 35 million mentally retarded people in the world, an average of 6 out of 1000 people in the world with autism, the United Nations Educational Scientific and Cultural Organization (UNESCO, 2011). March 2013, the United States reported, there was an increase in prevalence to 1:50 in the past year. This does not only happen in developed countries such as Britain, Australia, Germany, and America but also occurs in developing countries such as Indonesia (Hurul, 2016).

Based on the main data of SLB East Java in 2010, seen from the school-age group, the total population in Indonesia with mental retardation is 62,011 people. Of these children with very severe mental retardation were called idiots as much as $2.5 \%$, children with severe mental retardation were $2.8 \%$, severe mental retardation was called imbecile debil profound as much as $2.6 \%$, children with mild mental retardation or weakness were 3,5\% and the rest are called dumb children (Depdiknas, 2010). From the results of the preliminary study for Pare District, most of them attend SLB Dharma Wanita Pare with a total of 40 students, covering elementary, junior high, and high school levels.

Parents who have children with mental retardation play a very important role in their development process. The responsibility and role of parents are very important for children with mental health disorders to help develop social adaptive behavior, namely the ability to be independent, therefore parents must know the most effective way to use it. Independent is the ability to stand alone on one's own feet with courage and responsibility. Independence is also influenced by factors, namely the education system, schools, the system of life in society, and the role of parents in which there are needs for foster care, love, and sharpening so that independence is complete (Andarsih, 2012).

With the symptoms and behaviors experienced by mentally retarded children, children with mental retardation disorders need early and intensive treatment to help optimize their development because caring for children with intellectual disabilities is quite a difficult task. This is where parents play a role in the child's condition, which has an impact on parents' attitudes and parenting towards children during their development. So that, not a few parents have the potential to experience stress, frustration, disappointment, and depression in their care. A large number of burdens felt by parents as the closest figure to the child in caring for them will cause stress in their upbringing which causes them to not be optimal in providing care and affection (Dharma, 2012).

At SLB C Dharma Wanita Pare, several mothers were seen waiting for their children during the learning process. From the results of the interview, there were still mothers who were less able to accept the fact that the condition of their children was different from the fact that their children were mentally retarded. When the mother finds out that her child is mentally retarded, the mother feels sad and disappointed with the situation that has befallen her, complains, and is angry with God why she should be gifted with a mentally retarded child.

The unfavorable psychological condition experienced by mothers of children with mental retardation does not necessarily make them off the hook for carrying out caring duties for their children. Mothers need coping mechanisms to deal with stress and are mentally healthy to do their job of raising children. Poor mental health conditions are closely related to the psychological well-being or psychological well-being of the parents of children with mental retardation. Caring for mentally retarded children has a significant impact on the psychological well-being of parents (Mawardah et al, 2012). 


\section{MATERIALS AND METHODS}

The type of research used was pre-experimental, namely experimental research design that aims to determine the effect of mindfulness therapy treatment on increasing psychological well-being of mothers with mentally retarded children using The One Group Pretest Posttest approach.

The population in this study were all mothers of children with mental retardation in SLB-C Dharma Wanita Pare-Kediri. This study took a population in the mentally retarded class, amounting to 40 people.

The sample in this study were all parents who had children with mental retardation in SLB C Dharma Wanita Pare Kediri who met the sample criteria as many as 15 respondents using the purposive sampling technique. This study has 2 criteria, namely inclusion and exclusion. The following will explain the two criteria.

1. Inclusion criteria include:

a. Students with mental retardation at SLB C Dharma Wanita Pare Kediri and

b. Parents whose children are mentally retarded at SLB C Dharma Wanita Pare Kediri.

2. Exclusion criteria included:

Parents who meet the criteria but do not want to be included for certain reasons.

The instruments used were the SOP of Mindfulness-Based Stress Reduction therapy and 42 points of Psychological well-being questionnaire. Then the maximum score value is 126 and the minimum is 45.

\section{RESULTS}

\section{Respondent Demographics}

The characteristics of the respondents in this study were general data which included: age, education, occupation and marital status.

Table 1. Characteristics of Respondents at SLB C Dharma Wanita Pare Kediri

\begin{tabular}{clcc}
\hline No. & \multicolumn{1}{c}{ Characteristics } & $\mathrm{f}$ & $\%$ \\
\hline Age & & \\
\hline 1 & <20 years old & 1 & 6.7 \\
2 & 20-35 years old & 7 & 46.7 \\
3 & $>35$ years old & 7 & 46.7 \\
\hline Education & & \\
\hline 1 & Elementary School & 2 & 13.3 \\
2 & Junior High School & 2 & 13.3 \\
3 & Senior High School & 9 & 60.0 \\
4 & University & 2 & 13.3 \\
\hline Profession & & \\
\hline 1 & Housewife & 10 & 66.7 \\
2 & Farmer & 1 & 6.7 \\
3 & Entrepreneur & 2 & 13.3 \\
4 & Private & 2 & 13.3 \\
\hline Marital & Status & & \\
\hline 1 & Janda & 4 & 26.7 \\
2 & Kawin & 11 & 73.3 \\
\hline
\end{tabular}

Based on the table above, it is known that almost half of the respondents were 20-35 years old and> 35 years old, namely 7 respondents $(46.7 \%)$ respectively from a total of 15 respondents. Most of the respondents have a high school education, namely, 9 respondents $(60 \%)$, work as housewives as many as 10 respondents (66.7\%), and are married as many as 11 respondents $(73.3 \%)$ from a total of 15 respondents.

Table 2. Psychological Well Being in Mothers in Caring for Mental Retardation Before and After Mindfulness-Based Stress Reduction Therapy

\begin{tabular}{lccccc}
\hline & N & Min & Max & Mean & Sd \\
\hline $\begin{array}{l}\text { Psychological Well } \\
\text { Being Pre Test }\end{array}$ & 15 & 78 & 83 & 80,6 & 1,242 \\
\hline $\begin{array}{l}\text { Psychological Well } \\
\text { Being Post Test }\end{array}$ & 15 & 114 & 123 & 117,07 & 2,052 \\
\hline
\end{tabular}


Based on the table above, it is known that the average psychological well-being assessment score of mothers in caring for a mentally retarded child before the mindfulness-based stress reduction therapy is 80.6 with the lowest score is 78 and the highest is 83 from the maximum value of 84 . After the therapy, the average score psychological well-being of mothers in caring for mentally retarded children was 117.07 with the lowest score 114 and the highest 123 from the maximum score of 126.

Table 3. Results of Paired Sample T-Test

\begin{tabular}{lcccccccc}
\hline & \multicolumn{3}{c}{ Pre Test } & \multicolumn{4}{c}{ Post Test } & Paired Sample $T$ \\
\cline { 2 - 7 } & $\mathrm{N}$ & Mean & SD & $\mathrm{N}$ & Mean & SD & Test $(t)$ & $\rho$ \\
\hline Psychological Well Being & 15 & 80,6 & 1,242 & 15 & 117,07 & 2,052 & 100,347 & 0,000 \\
\hline
\end{tabular}

The table above shows the effect of mindfulness-based stress reduction therapy on psychological well-being in mothers of mentally retarded children at SLB C Dharma Wanita Pare Kediri ( $\rho$-value = $0,000<0.05$, so $\mathrm{H} 0$ was rejected). There is an effect of mindfulness-based stress reduction on psychological well-being in mothers of mentally retarded children at SLB C Dharma Wanita Pare Kediri.

\section{DISCUSSION}

\section{Mother's Psychological Well Being Before Mindfulness-Based Stress Reduction Therapy}

Based on the table above, it is known that the average score of psychological well-being assessments of mothers in caring for mentally retarded children before the mindfulness-based stress reduction therapy is 80.6 with the lowest score is 78 and the highest is 83 .

Psychological well-being refers to a person's feelings about the activities of daily life (Bradburn in Fransisca, 2005). According to Doyle, Hanks \& MacDonald psychological well-being are a reflection of happiness, emotional well-being, and positive mental health (Bolang, 2012: 13). Ryff defines psychological well being as a condition in which individuals have a positive attitude towards themselves and others, can make their own decisions and regulate their behavior, can create and regulate an environment that is compatible with their needs, has a purpose in life, and makes life more meaningful, and trying to explore and develop themselves. According to Ryff, humans can be said to have good psychological well-being, namely having self-acceptance, positive relationships with others, autonomy, the ability to have a sense of personal growth, and sustainable development. Psychological well-being is the level of an individual's ability to accept himself as he is, determine warm relationships with others, be independent of social pressure, control the external environment, have meaning in life, and realize his potential continuously (Daniella, 2012: 2).

The results showed that the average psychological well-being assessment score of mothers in caring for a mentally retarded child before mindfulness-based stress reduction therapy was 80.6 with the lowest score of 78 and the highest was 83 . This can be interpreted that the mother's psychological well-being condition is classified as a score low in the sense that the psychological well-being conditions are also not good. This can be caused by various factors including age, gender, socioeconomic status, culture, social support, life experience, religious factors, and other factors such as heavy life burdens, for example when parents have to care for their children who have weaknesses such as mental retardation. . Therefore it is recommended to study the context of one's experience in its development to study external factors that can affect one's well being (economic development, the existence of friendship and the availability of adequate resources to achieve the stated goals (Diener, Suh, Lucas, et al. 2010).

From the description above, it can be concluded that the involvement and feelings of the mother greatly affect the social development of the child. Based on the results of research conducted by Huthala, Korja (2001), it was stated that the mother's psychological well-being would affect the child's cognitive and social-emotional development and vice versa. The first environment known to the child is the mother, so that if the mother experiences depression and dissatisfaction with her child's situation, indirectly the mother will also experience obstacles in giving attention and assistance to her child. To prevent this from happening, good psychological well-being is needed so that the role of the mother can function positively towards the situation being experienced. 


\section{Mother's Psychological Well Being After Mindfulness-Based Stress Reduction Therapy}

Based on the table above, it is known that the average score of psychological well-being assessments of mothers in caring for mentally retarded children after mindfulness-based stress reduction therapy is 117.07 with the lowest score 114 and the highest is 123 .

Mindfulness is a skill that can help individuals have awareness and not be reactive to what is happening today, a way to interpret positive, negative, and neutral events so that they can overcome feelings of depression and create self-welfare (Germer, Siegel, and Fulton, 2005: 68). Kabat-Zinn defines mindfulness as awareness that arises from paying attention to current experiences intentionally and without judgment to be able to respond with acceptance rather than react to everyday experiences. Baer (2003) states that mindfulness is an observation of the emergence of internal and external stimuli as they are and without judgment. According to Kabat Zinn (2003), mindfulness is an awareness that arises through the experience of the current moment, without judgment from time to time.

Several studies have shown a significant relationship between mindfulness and psychological well-being. Research conducted by Collard, Anvy, and Bonivwell (2008) shows that mindfulnessbased stress reduction has a positive effect on PWB. In this study, the positive effect of the participants did not increase, while the negative effect of the participants did not increase. The level of life satisfaction has been shown to have increased, but it does not appear to be significant.

The average psychological well-being assessment score for mothers in caring for mentally retarded children after mindfulness-based stress reduction therapy was 117.07 with the lowest score 114 and the highest being 123. This can be interpreted that the mother's psychological well-being condition is good enough. This shows that mindfulness-based stress reduction therapy can change the psychological condition of mothers whose children are mentally retarded. The life burden that is felt at this time is because they have to serve their children, help their children's basic needs, and the psychological burden because their children have developmental weaknesses, can be controlled and neglected by the mother so that the mother can let go of her life burdens a little.

\section{The Effect of Mindfulness-Based Stress Reduction Therapy on Psychological Well Being in Mothers of Mental Retarded Children}

Based on table 4.8, it is known that there is an effect of mindfulness-based stress reduction therapy on psychological well-being in mothers of mentally retarded children at SLB C Dharma Wanita Pare Kediri in 2018 ( $\mathrm{p}=0.000<0.05$, so Ho is rejected).

Wahyuningtiyas (2016) states good psychological well-being is characterized by considering childcare is important and committed to maintaining good childcare, managing thoughts, and feelings to deal with it, accepting yourself well, having positive relationships with others, and controlling the environment. the surroundings. Several interventions to improve psychological well-being include mindfulness (full awareness) (Jenifer et al, 2013). Mindfulness begins with bringing awareness of the experience here to the moment. Increased focus of attention results in awareness of thoughts, feelings, and sensations so that they are fully aware of reality. A state of acceptance in mindfulness appears as an experience of current reality (Anastasia, 2016). Mindfulness is related to the ability to see the relationship of thoughts, feelings, and activities so that fully conscious behavior emerges (Firstiyani, 2016).

In general, mindfulness meditation has several effects. Coffey and Hartman (2008) found that the ability to observe the flow of consciousness without judgment in mindfulness meditation can increase awareness and the ability to regulate emotions so that negative emotions can be managed adaptively. In mindfulness, the emotions that arise can be regulated using cognitive functions. Based on research conducted by Greeson (2009), the ability in mindfulness can increase equanimity and the ability not to respond to stimuli reactively (nonreactivity). In addition to the things above, mindfulness has also been shown to reduce stress by providing a relaxing effect, increasing the ability to accept, and changing cognitive function to be more adaptive (Baer, 2003). Instead of thinking of thoughts as reality, individuals can perceive thoughts or thoughts that appear as just thoughts.

Several studies have shown a significant relationship between mindfulness and psychological well-being. Research conducted by Collard, Anvy, and Bonivwell (2008) shows that mindfulnessbased stress reduction has a positive effect on PWB. In this study, the positive effects of participants did not increase, while the negative effects of participants did not increase. The level of life satisfaction is shown to have increased, but it does not appear to be significant. 


\section{CONCLUSION}

1. The average score of psychological well-being assessment of mothers in caring for mentally retarded children before the mindfulness-based stress reduction therapy is 80.6 with the lowest score is 78 and the highest is 83 .

2. The average score of psychological well-being assessments of mothers in caring for mentally retarded children after mindfulness-based stress reduction therapy was 117.07 with the lowest score of 114 and the highest of 123.

3. In addition to increased psychological well-being scores, mindfulness exercises can also provide a sense of calm, comfort, foster a sense of pride and respect for oneself, work, and others.

4. The benefits of mindfulness training will be more optimal as long as its implementation continues to use the principles of mindfulness, namely: awareness (awareness), current experience or focus on current events, acceptance, and is carried out routinely in everyday life.

\section{ACKNOWLEDGMENTS}

Thank you to all respondents who were willing to be sampled in our research.

\section{CONFLICTS OF INTEREST:}

The author declares that they have no conflict of interest

\section{REFERENCES}

Anastasia. (2016). Pengaruh Pelatihan berbasis mindfulness terhadap tingkat stress pada guru paud.

Dharma (2012). Pengaruh pelatihan meditasi sadar diri terhadap penurunan tingkat distres remaja yang mengalami kehamilan pranikah.

Fitriya, Lestari. (2014). Peningkatan Interaksi Ibu dan Anak Retardasi Mental melalui Pelatihan Bermain Pura-pura. V ol.41 No.2 ISSN. pp.165-178.

Hurul (2016). Kesehatan mental pada orang tua yang memiliki anak retaradasi mental.

Mawardah, Siswati, Farida. (2012). Relationship Retween Active Coping with Parenting Stress in Mother of Mentally Retarded Child. Vol.1 No.1.

Mccaffcey (2015). Mindfulness based cognitive therapy untuk meningkatkan konsep diri remaja post taaumtaic stress disorder. Vol. 8. No.2. Jurnal Internasional Psychologi.

Mubashir. (2015). Mental retardaion: Early Idenificaion and Prevention. Vol.2 No.3. ISSN 2348-5396. pp. 213-220. The Inernaional Journal of Indian Psychology.

Pajar (2016). Program pengasuhan positif untuk meningkatkan keterampilan mindful parenting orang tua remaja. Vol.3. no. 1. Jurnal ilmiah psikologi.

Patricia (2014). Bagaimana hubungan religiusitas dengan resitensi pada ibu yang memiliki anak retardasi mental.

Samantha (2012). Factor the Impact the health and psychological well being of older adults shortly following instutional zation.

Soetjiningsih. (2013). Tumuh Kemang Anak Edisi 2. Jakara: EGC.

Sulastoyo, Noor (2008). Mindfulness dan Depresi pada Remaja Puri.

Sunaryo, M.Kes. (2004). Psikologi untuk Keperawatan. Jakarta: EGC.

Swarjana, I Ketut. (2012). Metodologi Penelitian Kesehatan. Yogyakarta: Andi Offset.

Thresia, Enjang (2016). Hubungan antara gratitude dengan psychological well being ibu yang di miliki anak tunagrahita di SLB negeri salatiga Vol. 32 pp. 57-64.

Ummiyah, Afiatin. (2009). The effect of Mindfulness training to Enhance the Empaty Level of health care profesional. Vol.1 No.1

Wardiyah (2013). Group positie psychoherapy untuk meningkatkan kesejahteraan psikologis remaja Vol. 1 No.2. pp. 11-17. ISSN.139-152. 